\title{
ASSOCIATION OF EGF, IGFBP-3 AND TP53 GENE POLYMORPHISMS WITH MAJOR DEPRESSIVE DISORDER IN SLOVAK POPULATION
}

\author{
Silvia Mahmood ${ }^{1,2}$, Andrea Evinová2, Mária Škereňová3, Igor Ondrejka ${ }^{4}$, Ján Lehotský2, 5 \\ ${ }^{1}$ Department of Molecular Medicine, Jessenius Faculty of Medicine in Martin, Comenius University in Bratislava, Biomedical Centre Martin \\ (BioMed Martin), Martin, Slovakia \\ 2Department of Medical Biochemistry, Jessenius Faculty of Medicine in Martin, Comenius University in Bratislava, Martin, Slovakia \\ ${ }^{3}$ Department of Clinical Biochemistry, Jessenius Faculty of Medicine in Martin, Comenius University in Bratislava, Martin University Hospital, \\ Martin, Slovakia \\ ${ }^{4} \mathrm{~J} e s s e n i u s$ Faculty of Medicine in Martin, Comenius University in Bratislava, Clinic of Psychiatry, Martin University Hospital, Martin, Slovakia \\ ${ }^{5}$ Department of Neurosciences, Jessenius Faculty of Medicine in Martin, Comenius University in Bratislava, Biomedical Centre Martin (BioMed \\ Martin), Martin, Slovakia
}

\section{SUMMARY}

Background: Major depressive disorder (MDD) is a main public health concern worldwide. Despite extensive investigations, the exact mechanisms responsible for MDD have not been identified. Epidermal growth factor (EGF) and insulin growth factor binding protein-3 (IGFBP-3) are involved in brain function. Tumour suppressor protein p53 is widely involved in neuronal death in response to different forms of acute insults and neurological disorders. The present study focuses on the possible associations of the single-nucleotide polymorphisms (SNP) of EGF A61G (rs4444903), IGFBP-3 C32G (rs2854746) and TP53 G72C (rs1042522) genes with MDD risk in the Slovak population.

Methods: The present case-control association study was carried out in 111 confirmed MDD patients and 207 healthy subjects. Genotyping was performed by polymerase chain reaction-restriction fragment length polymorphism methods.

Results: Logistic regression analysis showed no association between SNPs of selected genes and MDD risk in the Slovak population. However, the stratification of individuals by gender revealed that males carrying IGFBP-3 G alleles (G32G or GG) had marginally increased risk for developing MDD as compared to CC homozygous males $(p=0.09)$. In women, inverse association was observed between SNP rs 1042522 and MDD risk ( $\mathrm{p}=0.04$ for recessive model).

Conclusion: Our results suggest the protective effect of minor allele 72C of TP53 gene towards MDD. The disruption of mechanisms involved in cell survival and death regulation may be involved in pathophysiology of MDD.

Key words: major depressive disorder, EGF, IGFBP-3, p53, SNP, Slovak population

Address for correspondence: J. Lehotský, Comenius University in Bratislava, Jessenius Faculty of Medicine in Martin, Biomedical Centre Martin, Department of Neurosciences, Mala Hora 4D, 03601 Martin, Slovakia. E-mail: lehotsky@jfmed.uniba.sk

http://dx.doi.org/10.21101/cejph.a4301

\section{INTRODUCTION}

Neuropsychiatric disorders are the second cause of disabilityadjusted life years (DALYs) in Europe (19\%), with only 4\% after cardiovascular disorders. It is estimated that $27 \%$ of the adult (18-65 years of age) EU population (including Iceland, Norway and Switzerland) suffer from at least one mental disorder (1) and almost every second person in the EU is or has been affected by mental disorders at some point in the lifetime. There is a significant gender gap concerning the depression as it is approximately twice as prevalent in women as it is in men in all EU countries. Even so, some of the Eastern and Northern European countries (e.g. Ireland, Slovakia and some Nordic countries) show bigger gender differences (2). Moreover, depression is substantially more common in patients with medical illness than it is in general population. For example, approximately $10 \%$ to $20 \%$ of patients with acute cardiac disease, diabetes, renal failure, or cancer also suffer from major depressive disorder (MDD) (3). However, assessing whether a medication has in fact caused depression or whether the relationship is coincidental can be challenging.

MDD is a subtype of unipolar depressive disorders that are the third cause of DALYs (5.6\%). Genetic factors are one of the most important in the development of MDD, as indicated by family, twin and adoption studies (4). Since for the clinicians is difficult to collect samples from the central nervous system (CNS) environment, developing readily available biomarkers in peripheral tissues such as blood, serum or plasma provide a potential road of research. Accordingly, it is plausible that identifying susceptibility genes may eventually lead to targeted "cure therapeutics" (5), giving impulse to identifying the underlying susceptibility genes and genetic factors associated with MDD. 


\section{Role of Growth Factors in Development of MDD}

One of the pathophysiological hypotheses states that abnormal neurogenesis may result in a malfunctioning hippocampus and decrease in the production of newborn dentate granule cells contributing to the deficits of cognitive, emotional and behavioural functioning observed in depressed patients and patients with neurodegenerative disorders such as Alzheimer's disease. Conversely, enhanced neurogenesis is beneficial and viewed necessary for the antidepressant treatment in rodent models (6). Several neurotrophic/growth factors affect the neurogenesis, including brain-derived neurotrophic factor (BDNF), fibroblast growth factor-2 (FGF-2), epidermal growth factor (EGF), insulin-like growth factor 1 (IGF-1), and neuropeptide vascular endothelial growth factor (7). Functional studies demonstrate that stress-induced changes in levels of these neurotrophic/ growth factors result in consequences in behavioural models of depression $(8,9)$.

\section{Insulin-like Growth Factor Binding Protein-3}

Insulin-like growth factors are a large family of insulin related peptides including IGF-1 and IGF-2 as well as their cell surface receptors (IGF-1R and IGF-2R), insulin like growth factors binding proteins (IGFBP-1-6), IGFBP proteases and several other IGFBP-interacting molecules which all regulate cell proliferation, differentiation and apoptosis (10). IGF-1 may increase the synthesis and activity of BDNF, and both factors are required to enhance neuronal survival and plasticity in the brain. IGF-1 exhibits multiple neurotrophic, neurogenic and neuroprotective actions. IGF-1 is mainly produced in the CNS and peripheral tissues such as liver. Moreover, it can penetrate through blood-brain barrier (BBB), which is crucial for the development of biomarkers for MDD or bipolar disorder (BD). In addition, IGF-1 can mediate antidepressant effect in MDD patients and its levels in the cerebrospinal fluid have been found to vary with antidepressant treatment (11). Currently, several studies have provided evidence about higher serum IGF-1 levels in MDD or bipolar disorder patients than in controls (11-14). More than $90 \%$ of the circulating IGF-1 is bound to IGFBP-3, which regulates the biological activity and availability of IGF-1. IGFBP-3 (OMIM \#146732) is a multifunctional protein that is found to play a variety of roles in regulating cell proliferation and apoptosis (15). Mature deglycosylated human IGFBP-3 has a molecular weight of $28.7 \mathrm{kDa}$ and comprises 264 amino acids. Using in vitro culture system of rat neural progenitor cells and animal models, the potential regulation role of IGFBP-3 in neurogenesis was demonstrated $(16,17)$. IGFBP-3 expression was increased after brain insults and upregulated in the brains of patients with Alzheimer's disease (18). Meanwhile, two genetic variants were mainly reported to link to IGFBP-3 with effect on the circulating level of IGFBP-3. One is a promoter SNP located at position -202 (rs2854744) resulting in a reduced promotor activity and decreased IGFBP-3 levels (19, 20). The other one is non-synonymous substitution of Gly to Ala at codon 32; Gly32Ala (rs2854746) (21), located in the region responsible for IGF-1 binding (22). Because of the biological significance of the IGFBP-3 gene and a lack of studies of the effect of polymorphisms in this gene on MDD risk, we aimed to determine whether the IGFBP-3 Gly32Ala polymorphism is associated with MDD risk.

\section{Epidermal Growth Factor}

The epidermal growth factor (OMIM\#121530) is a small protein (6045 Da) and consists of 53 amino acid residues (23). The $E G F$ gene, located at 4q25-27, encodes a ligand EGF for the epidermal growth factor receptor (EGFR) on the cell membrane that triggers the intrinsic protein tyrosine kinase activity and activates a series of intracellular signaling networks (24). On the basis of the neurotrophin hypothesis, EGF signal regulates the development of dopaminergic neurons and monoamine metabolism $(25,26)$. Previous studies indicated an association of MDD as well as schizophrenia with EGF abnormal or dysfunctional expression $(27,28)$. Schizophrenia has been shown to be associated with the functional SNP in the $5^{\prime}$ untranslated region of the $E G F \mathrm{~A} 61 \mathrm{G}$ (rs4444903) promoting $E G F$ transcription $(29,30)$. Besides, the substitution of guanine (G) for adenine (A) at position 61 increased the serum level of EGF in cultured peripheral blood mononuclear cells (31) and thus $E G F$ genotypes may be involved in the modulation of midbrain dopaminergic neurons development. Due to the essential role of EGF in the development of the brain and especially in the development of the dopaminergic neurotransmission, we tested the hypothesis that functional $E G F \mathrm{~A} 61 \mathrm{G}$ polymorphism might contribute to the development of MDD.

\section{Role of Tumour Suppressor Gene TP53}

p53 (OMIM \#1911170) is a nuclear phosphoprotein involved in DNA repair, cell cycle progression, and apoptosis (32). It has been reported that p53 is involved in an early stage of brain development and might constitute a candidate susceptibility gene for mental as well as neurodegenerative disorders and its neurocognitive deficits (33). Additionally, increased apoptosis in frontal cortex and smaller brain tissue volumes, decreased neuropil and fewer neuronal progenitor cells observed in patients suffering from MDD (34) include apoptosis in the aetiology of disease. Several polymorphisms have been identified within TP53 gene, both in noncoding and coding regions (35). The best studied human TP53 apoptosis-associated polymorphism G72C (rs 1042522) arises from a single-base-pair substitution at codon 72 , where either CCC encodes proline instead CGC encodes arginine (hereinafter designated as Arg72Pro) (36). Codon 72 is in exon 4 in the segment of TP53 that encodes the polyproline domain which has been shown to be important for $\mathrm{p} 53$ function, especially for its ability to induce apoptosis (37). The both variants exhibit different abilities to activate gene expression, since Arg72 variant induces apoptosis and suppresses transformation more efficiently than the Pro72 variant (36). It has been recently established that this polymorphism impacts the apoptotic function of $\mathrm{p} 53$ in a tissue- and age-specific manner along with ethnicityspecific genetic background and environmental exposure $(24,38)$.

In the present study we investigate the possible association between the independent TP53 Arg72Pro, EGF A61G and IGFBP-3 $\mathrm{G} 32 \mathrm{C}$ gene polymorphisms and MDD risk in the Slovak population.

\section{MATERIALS AND METHODS}

\section{Study Population}

The case group comprised 111 patients (from 19-82 years, median 51$), 61.3 \%$ were women with average age $50.9 \pm 11.6$ 
(from 19-82 years, median 53) and 38.7\% were men with average age $47.3 \pm 10.9$ (from 21-71 years, median 49), suffering from MDD with single or recurrent episode. Diagnoses were established according to the Diagnostic and Statistical Manual of Mental Disorders (DSM-IV-TR) and the ICD-10 Classification of Mental and Behavioural Disorders (ICD-10) criteria. Two independent expert psychiatrists interviewed all of the patients. Diagnosis of bipolar disorder led to exclusion from the study. For the complexity of diagnosis a rating scale (MADRS score) was used too. Patients with primary depression were hospitalized from four to seven weeks at the Psychiatric Clinic of University Hospital Martin (Slovakia) after the failure of ambulance treatment. The control group comprised 207 healthy volunteers (median 56 years) who visited the general health check-up or medical and paramedical staff. The composition of the control group was comparable to the cases in terms of ethnicity (Caucasian - Central European only), age and gender $(61.4 \%$ of women with average age $46.5 \pm 13.7$, median 48.5 ; and $38.6 \%$ of men with average age $55.6 \pm 14.1$, median 56). Exclusion criteria for controls: blood relatives who had been diagnosed with MDD. Inclusion criteria was age $>18$. The present study was approved by the Ethical Board of Jessenius Faculty of Medicine, Comenius University and the written informed consent was obtained from all individuals prior to the study.

\section{Genotype Analysis}

Genomic DNA was isolated from peripheral leukocytes by proteinase $\mathrm{K}$ digestion (Applichem, Germany), phenol/chloroform extraction and ethanol precipitation, dissolved in TE buffer $(\mathrm{pH}=7.5)$ and stored at $-20^{\circ} \mathrm{C}$ until genotype analysis.

Genomic DNA (100 ng) was amplified in a total volume of $25 \mu \mathrm{l}$ reaction mixture containing $25 \mathrm{pmol}$ of the either exon 1 IGFBP-3 gene sequence primers, (forward 5'-TTCCTGCCTGGATTCCACAGCTT-3' and reverse 5'-GGCACTAGCGTTGACGCAGA-3') or exon 4 TP53 (forward 5'-TTGCCGTCCCAAGCAATGGATGA-3' and reverse 5'-TCTGGGAAGGGACAGAAGATGAC-3') or EGF gene sequence primers (forward 5'-TGTCACTAAAGGAAAGGAGGT-3' and reverse 5'-TTCACAGAGTTTAACAGCCC-3', VBC-Biotech, Austria), and RedTaq ReadyMix PCR reaction mix (20 mM Tris$\mathrm{HCl}, \mathrm{pH} 8.3,100 \mathrm{mM} \mathrm{KCl}, 3 \mathrm{mM} \mathrm{MgCl}{ }_{2}, 0.002 \%$ gelatin, $0.4 \mathrm{mM}$ dNTP mix, stabilizers, and $0.06 \mathrm{unit} / \mu \mathrm{l}$ of Taq DNA Polymerase, Sigma-Aldrich, USA). In case of IGFBP-3, samples were initially denaturated for $5 \mathrm{~min}$ at $96^{\circ} \mathrm{C}$, then 35 cycles were performed for $30 \mathrm{sec}$ at $96^{\circ} \mathrm{C}$ (denaturation), for $45 \mathrm{sec}$ at $60^{\circ} \mathrm{C}$ (annealing) and for $60 \mathrm{sec}$ at $72^{\circ} \mathrm{C}$ (extension), followed by a final step for $5 \mathrm{~min}$ at $72^{\circ} \mathrm{C}$. In case of TP53 reaction mixtures were preincubated for $5 \mathrm{~min}$ at $94^{\circ} \mathrm{C}, 35$ cycles were performed for $40 \mathrm{sec}$ at $94^{\circ} \mathrm{C}$, for $30 \mathrm{sec}$ at $68^{\circ} \mathrm{C}$ and extension for $40 \mathrm{sec}$ at $72^{\circ} \mathrm{C}$, followed by a final step of $10 \mathrm{~min}$ at $72^{\circ} \mathrm{C}$. The PCR products were digested with 2 units of Aval in case of $I G F B P-3$ or 5 units of $B s t U I$ in case of TP53 (New England, Biolabs) at $37^{\circ} \mathrm{C}$ for 2 hours. After digestion, the fragments were electrophoresed on $2 \%$ agarose gel and visualized by UV light after ethidium bromide staining. Thus, the $\mathrm{G}$ allele of IGFBP-3 was identified by the presence of a $187 \mathrm{bp}$ and $263 \mathrm{bp}$ fragments and $\mathrm{C}$ allele by single $450 \mathrm{bp}$ fragment (22). IGFBP-3 was evaluated with individuals being categorized as having a $C 32 C, G 32 C$, or $G 32 G$ genotype. In case of TP53, the proline allele was identified by the presence of a single fragment of $199 \mathrm{bp}$ and the arginine allele by two fragments of $113 \mathrm{bp}$ and $86 \mathrm{bp}$, respectively. Heterozygous (Arg72Pro) samples displayed all three fragments of $199 \mathrm{bp}, 113 \mathrm{bp}$ and 86 bp. Genotyping of EGF was done by PCR-RFLP as described previously (31). Briefly, the reaction mixtures were preincubated at $94^{\circ} \mathrm{C}$ for $5 \mathrm{~min}$, followed by 35 cycles at $94^{\circ} \mathrm{C}$ for $1 \mathrm{~min}, 57^{\circ} \mathrm{C}$ for $1 \mathrm{~min}, 72^{\circ} \mathrm{C}$ for $1 \mathrm{~min}$ and a final extension step at $72^{\circ} \mathrm{C}$ for $10 \mathrm{~min}$. The $E G F$ amplification product of the size $242 \mathrm{bp}$ was digested with 5 units of Alu1 (New England, Biolabs) at $37^{\circ} \mathrm{C}$ for 16 hours. Restriction enzyme digestion products G61G (193 bp, $34 \mathrm{bp}$, and $15 \mathrm{bp}$ ), A61A (102 bp, $91 \mathrm{bp}, 34 \mathrm{bp}$, and $15 \mathrm{bp}$ ), and A61G (193 bp, 102bp, 91 bp, 34 bp, and 15 bp) were analyzed using the Shimadzu MCE-202 MultiNA microchip technology and MultiNA Viewer software (Shimadzu Corporation, Kyoto, Japan). As a quality control, $10-20 \%$ of all samples were repeated as blinded duplicates.

\section{Statistical Analysis}

The Mann Whitney test was used to assess the differences between the frequency distribution of variables in cases and controls. Hardy-Weinberg equilibrium was tested using a goodness-of-fit $\chi^{2}$ test with one degree of freedom to compare observed genotype frequencies with expected genotype frequencies among the subjects. Odds ratios (OR), 95\% confidence intervals (CI) for OR and $\chi^{2}$ test were used to test frequencies of genotypes/allele in MDD patients and controls. ORs were calculated for all genetic models: codominant, dominant $(\mathrm{A} / \mathrm{G}+\mathrm{A} / \mathrm{A}$ vs. $\mathrm{G} / \mathrm{G})$, recessive $(\mathrm{G} / \mathrm{G}+\mathrm{A} / \mathrm{G}$ vs. A/A), additive (A/G vs. G/G+AA). Logistic regression was used that treats disease status as the outcome variable and genotype according to genetic model as an explanatory variable. Logistic models were adjusted for age and gender, if it was possible. The statistical programs Microsoft Excel and GraphPad Instat version 3.00 for Windows 95, GraphPad Software, San Diego California USA were used. Logistic regression was done using SNP and Variation Suite v8 (39). All tests were two-sided and considered significant if $\mathrm{p}<0.05$.

\section{RESULTS}

\section{Study Population}

In total, 111 cases and 207 controls of Slovak Europeans were included in this analysis. Mann Whitney statistics tested no significant differences between age distributions in case and control study groups $(\mathrm{p}>0.05)$. Statistical analysis did not reveal difference related to gender distribution between the groups investigated as well $\left(x^{2}=0.0003, p=0.99\right)$.

\section{Prevalence of IGFBP-3 G32C Genotypes in MDD Patients}

No significant deviation from expected genotype frequencies under Hardy-Weinberg equilibrium was observed in the control group. However, IGFBP-3 genotype distribution of the men control group was not in agreement with Hardy-Weinberg equilibrium $\left(\chi^{2}=4.77, \mathrm{p}<0.05\right)$. Table 1 shows the frequencies of IGFBP-3 genotypes in MDD patients and control group. Fisher test and $\chi^{2}$ 
Table 1. Frequency distribution of IGFBP-3 C32G, EGF A61G or TP53 Arg72Pro polymorphisms adjusted for gender and age

\begin{tabular}{|c|c|c|c|c|c|c|}
\hline \multirow[t]{2}{*}{ Genotypes } & \multicolumn{2}{|c|}{$\begin{array}{l}\text { Cases } \\
(\mathrm{N}=111)\end{array}$} & \multicolumn{2}{|c|}{$\begin{array}{l}\text { Controls } \\
(\mathrm{N}=207)\end{array}$} & \multirow[t]{2}{*}{ OR $(95 \% \mathrm{Cl})$} & \multirow[t]{2}{*}{$p$ value } \\
\hline & $\mathrm{n}$ & $\%$ & $\mathrm{n}$ & $\%$ & & \\
\hline \multicolumn{7}{|l|}{ IGFBP-3 C32G } \\
\hline $\mathrm{CC}$ & 40 & 36.04 & 76 & 36.71 & 1.00 & \\
\hline GC & 53 & 47.75 & 105 & 50.72 & $0.95(0.58-1.60)$ & 0.97 \\
\hline GG & 18 & 16.22 & 26 & 12.56 & $1.30(0.65-2.70)$ & 0.50 \\
\hline$G C+G G$ vs $C C$ & 71 & 63.96 & 131 & 63.29 & $0.99(0.61-1.61)$ & 0.97 \\
\hline$G C$ vs $C C+G G$ & 58 & 52.25 & 102 & 49.28 & $1.10(0.78-1.57)$ & 0.57 \\
\hline$C C+G C$ vs $G G$ & 93 & 83,78 & 181 & 87.44 & $1.48(0.76-2.88)$ & 0.25 \\
\hline \multicolumn{7}{|l|}{ EGF A61G } \\
\hline AA & 41 & 36.94 & 85 & 41.06 & 1.00 & \\
\hline$A G$ & 48 & 43.24 & 90 & 43.48 & $1.10(0.70-1.80)$ & 0.70 \\
\hline GG & 22 & 19.82 & 32 & 15.46 & $1.40(0.70-2.75)$ & 0.30 \\
\hline$A G+G G$ vs $A A$ & 70 & 63.06 & 122 & 58.94 & $1.17(0.72-1.91)$ & 0.52 \\
\hline$A G$ vs $A A+G G$ & 63 & 56.76 & 117 & 56.52 & $1.12(0.81-1.55)$ & 0.50 \\
\hline$A A+A G$ vs $G G$ & 89 & 80.18 & 175 & 84.54 & $1.16(0.62-2.15)$ & 0.65 \\
\hline \multicolumn{7}{|c|}{ p53 $\operatorname{Arg} 72$ Pro $(C \rightarrow G)$} \\
\hline $\mathrm{CC}$ & 59 & 53.15 & 111 & 53.62 & 1.00 & \\
\hline CG & 41 & 36.94 & 80 & 38.65 & $0.96(0.60-1.60)$ & 0.90 \\
\hline GG & 6 & 5.41 & 16 & 7.73 & $0.70(0.26-1.90)$ & 0.50 \\
\hline$C G+G G$ vs $C C$ & 47 & 42.34 & 96 & 46.38 & $0.87(0.54-1.40)$ & 0.57 \\
\hline$C G$ vs $C C+G G$ & 65 & 58.56 & 127 & 61.35 & $0.86(0.58-1.26)$ & 0.43 \\
\hline $\mathrm{CC}+\mathrm{GC}$ vs $\mathrm{GG}$ & 100 & 90.09 & 191 & 92.27 & $0.67(0.25-1.79)$ & 0.42 \\
\hline
\end{tabular}

test showed no significant association between IGFBP-3 G32C gene polymorphism and MDD risk. However, subgroup analysis by gender has revealed marginally significant increased risk of MDD in men patients in a dominant model $(\mathrm{p}=0.09)$ (Table 2) suggesting that $I G F B P-3$ GG genotype might increase MDD risk in men whereas this genotype may be a potential protective factor in women with diagnosed MDD (Table 3).

\section{Prevalence of $E G F$ A61G Genotypes in MDD Patients}

Genotype frequencies of $\mathrm{A} 61 \mathrm{G}$ polymorphism of $E G F$ gene are listed in Table 1. Subgroup analysis by gender has shown that the genotype $E G F \mathrm{G} 61 \mathrm{G}$ as well as allele $\mathrm{G}$ was associated with non significantly increased risk of MDD in women (Table 3). In contrast, $\mathrm{G}$ allele and $E G F$ G61G genotype has shown to be protective regarding the MDD risk in men (Table 2).

\section{Prevalence of TP53 Arg72Pro Genotypes in MDD Patients}

Genotype frequences of TP53 Arg72Pro polymorphism (Table 1) indicate that individuals homozygous for the Arg allele have higher frequency than other alleles and that MDD may be related to Arg allele frequency. Logistic regression analysis showed no significant association of TP53 Arg72Pro genotypes with MDD after adjustment for gender and age. However, an inverse association between Pro72 (C) variant allele of TP53 gene and
MDD risk $(p=0.04)$ was revealed by using recessive model in women (Table 3 ).

\section{DISCUSSION}

Since neutrophins and neurodegeneration appear to play critical role in the pathophysiology of MDD, we investigated the contribution of the IGFBP-3 G32C, EGF A61G and TP53 Arg72Pro polymorphisms to MDD risk in the Slovak population. This is the first study showing a possible association of the above mentioned genetic polymorphic variants with MDD risk.

Due to ability of IGF-1 to influence many processes such as adult neurogenesis, synaptic plasticity, neuromodulation, myelination and remyelination, it has been suggested that disturbances in the IGF-1 system are involved in the development of affective disorders (40). Besides, IGF-1 level was shown to be elevated in patients with MDD $(11,40)$ suggesting that peripheral IGF-1 levels may be a disease trait marker or indicator of cognition. Although, it has been estimated that up to $60 \%$ of the variance in IGF-1 serum level has a genetic basis (41), results of studies that evaluated the relationship between the IGF-1 polymorphisms and IGF-1 levels are contradictory (42). Recent results on healthy middle-aged Caucasian individuals confirm the association between IGF-1 polymorphisms and IGF-1 levels but found no association between IGF-1 polymorphisms and IGF-1 levels with cognitive functioning $(\mathrm{n}=698)(42)$. IGFBP-3, an 
Table 2. Frequency distribution of selected polymorphisms between men cases and controls and its association with risk of MDD adjusted for age

\begin{tabular}{|c|c|c|c|c|c|c|}
\hline \multirow[t]{2}{*}{ Genotypes } & \multicolumn{2}{|c|}{$\begin{array}{l}\text { Cases } \\
(\mathrm{N}=43)\end{array}$} & \multicolumn{2}{|c|}{$\begin{array}{c}\text { Controls } \\
(\mathrm{N}=80)\end{array}$} & \multirow[t]{2}{*}{ OR $(95 \% \mathrm{Cl})$} & \multirow[t]{2}{*}{$p$ value } \\
\hline & $\mathrm{n}$ & $\%$ & $\mathrm{n}$ & $\%$ & & \\
\hline \multicolumn{7}{|l|}{ IGFBP-3 C32G } \\
\hline $\mathrm{CC}$ & 15 & 34.88 & 28 & 35.00 & 1.00 & \\
\hline GC & 19 & 44.19 & 46 & 57.50 & $0.80(0.34-1.76)$ & 0.50 \\
\hline GG & 9 & 20.93 & 6 & 7.50 & $2.80(0.84-9.40)$ & 0.10 \\
\hline$G C+G G$ vs $C C$ & 28 & 65.12 & 52 & 65.00 & $0.74(0.32-1.68)$ & 0.47 \\
\hline CG vs CC + GG & 24 & 55.81 & 34 & 42.50 & $1.10(0.60-2.03)$ & 0.76 \\
\hline$C C+G C$ vs $G G$ & 34 & 79.07 & 74 & 92.50 & $2.76(0.81-9.37)$ & 0.09 \\
\hline \multicolumn{7}{|l|}{ EGF A61G } \\
\hline$A A$ & 18 & 41.86 & 28 & 35.00 & 1.00 & \\
\hline$A G$ & 16 & 37.21 & 36 & 45.00 & $0.70(0.30-1.60)$ & 0.40 \\
\hline GG & 9 & 20.93 & 16 & 20.00 & $0.88(0.32-2.40)$ & 0.80 \\
\hline$A G+G G$ vs $A A$ & 25 & 58.14 & 52 & 65.00 & $0.87(0.39-1.95)$ & 0.74 \\
\hline$A G$ vs $A A+G G$ & 27 & 62.79 & 44 & 55.00 & $0.87(0.52-1.47)$ & 0.61 \\
\hline$A A+A G$ vs $G G$ & 34 & 79.07 & 64 & 80.00 & $0.75(0.28-2.03)$ & 0.57 \\
\hline \multicolumn{7}{|c|}{ p53 Arg72Pro $(\mathrm{C} \rightarrow \mathrm{G})$} \\
\hline $\mathrm{CC}$ & 21 & 48.84 & 43 & 53.75 & 1.00 & \\
\hline CG & 15 & 34.88 & 32 & 40.00 & $0.95(0.40-2.20)$ & 0.90 \\
\hline GG & 5 & 11.63 & 5 & 6.25 & $2.05(0.50-7.80)$ & 0.30 \\
\hline$C G$ + GG vs CC & 20 & 46.51 & 37 & 46.25 & $0.97(0.44-2.14)$ & 0.94 \\
\hline$C G$ vs $C C+G G$ & 26 & 60.47 & 48 & 60.00 & $1.06(0.58-1.95)$ & 0.85 \\
\hline$C C+C G$ vs GG & 36 & 83.72 & 75 & 93.75 & $1.48(0.38-5.83)$ & 0.58 \\
\hline
\end{tabular}

important regulator of cell responsiveness to IGF-1, is the most abundant IGFBP protein in the bloodstream and is expressed at a low level in the CNS, mainly in nonneuronal structures including epithelial cells. Associations with circulating IGFBP-3 have been previously evaluated with cardiovascular disease, diabetes and cancer (43). Contradictory results were published regarding the association between the IGFBP-3 level and cognitive changes. Duron et al. (44) found that low IGF-1 and IGFBP-3 serum levels were significantly associated with age-related cognitive changes and development of dementia in men with Alzheimer's disease $(n=694)$. In another study of men $(n=746)$, similar results were found regarding the relation between IGFBP-3 and IGF-2 but not IGF-1 and cognitive aging and development of dementia (45). On the contrary, Johansson et al. (46) in a small cross-sectional study of patients found increased serum but not cerebrospinal fluid levels of IGF-1 and IGFBP-3 in patients with AD $(n=60)$. In German epidemiologic KORA-Age study (47), IGFBP-3 was positively associated with well-being in women and less so in men whereas IGF-1 was positively correlated with depression and negatively with well-being $(\mathrm{n}=985)$. Here, opposite and independent associations of IGF-1 and IGFBP-3 on well-being particularly in women suggest for the neuroprotective effects of IGFBP-3 in cognitive aging. Previous studies have shown that genetic factors are important determinants of circulating IGFBP-3 levels. Five IGFBP-3 SNPs (rs3110697, rs2854747, rs2854746, rs2854744, rs2132570) were highly correlated with IGFBP-3 level in the multiethnic cohort study including white men and women $(n=826)(48)$. They observed consistently lower levels of IGFBP-3 in the presence of the minor allele across five racial/ ethnic groups. Because IGFBP-3 is the principal binding protein of circulating IGF-1, lower levels of IGFBP-3 due to genetic variation may increase the bioavialability of IGF-1 and bioactivity of IGF-1 in circulation and tissues. In the study of African American and Caucasian women, the IGFBP-3 SNP rs2854746 (Ala32Gly) was shown to be associated with plasma IGFBP-3 (49). In the present study we investigated the correlation between rs 2854746 polymorphism of $I G F B P-3$ gene and MDD risk. We did find no association between the IGFBP-3 SNP rs 2584746 and MDD risk. However, some gender differences were noted when the variant genotype IGFBP-3 G32G was associated with a marginally significant increased risk of MDD in men $(\mathrm{p}=0.1)$ but not in women. The question remains whether this gender difference may be the effect of sex hormones. Although sex hormones cannot change DNA sequence, it is known they can be potent modifiers of epigenetic status and gene expression (50). However, due to the nature of hospital-based case control study design and deviations from Hardy-Weinberg equilibrium in men, a potential selection bias should be taken into consideration when interpreting this result. Here, using hospital-based controls as well as medical and paramedical staff could generate Berkson bias which might influence the frequencies of IGFBP-3 genotypes and the susceptibility to MDD risk. Therefore, this result requires validation in a further 
Table 3. Frequency distribution of selected polymorphisms between women cases and controls and its association with risk of MDD adjusted for age

\begin{tabular}{|c|c|c|c|c|c|c|}
\hline \multirow[t]{2}{*}{ Genotypes } & \multicolumn{2}{|c|}{$\begin{array}{l}\text { Cases } \\
(\mathrm{N}=68)\end{array}$} & \multicolumn{2}{|c|}{$\begin{array}{l}\text { Controls } \\
(\mathrm{N}=127)\end{array}$} & \multirow[t]{2}{*}{ OR $(95 \% \mathrm{Cl})$} & \multirow[t]{2}{*}{$\mathrm{p}$ value } \\
\hline & $\mathrm{n}$ & $\%$ & $\mathrm{n}$ & $\%$ & & \\
\hline \multicolumn{7}{|l|}{ IGFBP-3 C32G } \\
\hline $\mathrm{CC}$ & 25 & 36.76 & 48 & 37.80 & 1.00 & \\
\hline GC & 34 & 50.00 & 59 & 46.46 & $1.10(0.58-2.10)$ & 0.80 \\
\hline GG & 9 & 13.24 & 20 & 15.75 & $0.86(0.34-2.17)$ & 0.80 \\
\hline$G C+G G$ vs $C C$ & 43 & 63.24 & 79 & 62.20 & $1.03(0.55-1.94)$ & 0.92 \\
\hline$C G$ vs $C C+G G$ & 34 & 50.00 & 68 & 53.54 & $0.97(0.62-1.51)$ & 0.88 \\
\hline$C C+G C$ vs $G G$ & 59 & 86.76 & 107 & 84.25 & $0.83(0.34-1.98)$ & 0.67 \\
\hline \multicolumn{7}{|l|}{ EGF A61G } \\
\hline AA & 23 & 33.82 & 57 & 44.88 & 1.00 & \\
\hline$A G$ & 32 & 47.06 & 54 & 42.52 & $1.50(0.80-2.80)$ & 0.30 \\
\hline GG & 13 & 19.12 & 16 & 12.60 & $2.00(0.82-4.80)$ & 0.10 \\
\hline$A G+G G$ vs $A A$ & 45 & 66.18 & 70 & 55.12 & $1.54(0.80-2.84)$ & 0.21 \\
\hline$A G$ vs $A A+G G$ & 36 & 52.94 & 73 & 57.48 & $1.31(0.84-2.02)$ & 0.23 \\
\hline$A A+A G$ vs $G G$ & 55 & 80.88 & 111 & 87.40 & $1.30(0.56-3.01)$ & 0.54 \\
\hline \multicolumn{7}{|c|}{ p53 Arg72Pro $(C \rightarrow G)$} \\
\hline $\mathrm{CC}$ & 38 & 55.88 & 68 & 53.54 & 1.00 & \\
\hline CG & 26 & 38.24 & 48 & 37.80 & $0.97(0.50-1.80)$ & 0.90 \\
\hline GG & 1 & 1.47 & 11 & 8.66 & $0.16(0.02-1.31)$ & 0.10 \\
\hline$C G+G G$ vs $C C$ & 27 & 39.71 & 59 & 46.46 & $0.79(0.42-1.46)$ & 0.45 \\
\hline$C G$ vs $C C+G G$ & 39 & 57.35 & 79 & 62.20 & $0.70(0.42-1.18)$ & 0.18 \\
\hline$C C+C G$ vs $G G$ & 64 & 94.12 & 116 & 91.34 & $0.18(0.02-1.42)$ & 0.04 \\
\hline
\end{tabular}

cohort. Furthemore, it remains to be determined whether this genetic variant may influence circulating IGFBP-3 level in MDD patients particularly with regard to different gender. Taking into account our results and previous findings we suggest that defect in $I G F B P-3$ may be involved in the development of MDD and we presume that gender specific expression of $I G F B P-3$ may enhance the risk for MDD among male patient with the G allele of rs2854746 but not for female with the $\mathrm{G}$ allele.

Concerning the EGF A61G polymorphism, there were no significant differences in genotype or allele frequencies between the patient and control groups, suggesting that this polymorphism does not affect the development of MDD. Previous studies in patients with schizophrenia showed similar results $(29,51,52)$. However, we observed some gender differences. The genotype EGF $\mathrm{G} 61 \mathrm{G}$ was associated with marginally significant increased risk of MDD in women $(p=0.10)$ whereas negative association was found in men. Previously, Lee et al. (30), in Korean study revealed that male patients with early onset schizophrenia $(n=190$ patients) were more likely to exhibit the common A61 A homozygote than male patients with adulthood onset schizophrenia suggesting that AA genotype might play a disease-modifying role differentially according to gender. In contrary, Anttila et al. (53) ( $\mathrm{n}=94)$ and Hänninen et al. (29) $(\mathrm{n}=149)$ in Finnish studies found EGF G61G genotype to be associated with schizophrenia in male patients. No association was found between treatment response and $E G F$ polymorphism. According to the study of Tian et al. (27)
( $n=463$ patients) among a Chinese population, the EGF levels in plasma were significantly lower in the patients with MDD than in the control group $(\mathrm{p}<0.001)$ showing EGF as a possible biomarker for the early diagnosis, treatment and prognosis of MDD. $E G F$ promoter polymorphisms were previously observed to modulate EGF levels and thought to have effect on susceptibility to various carcinomas but the results are contradictory (24). Thus, it will be compulsive to investigate effect of $E G F \mathrm{~A} 61 \mathrm{G}$ polymorphism on modulating EGF level in MDD patients.

Apoptosis, which is mainly under the control of the nuclear phophoprotein $\mathrm{p} 53$, has long been considered one of the likely factors in the aetiology of dysregulation process in the CNS of patients suffering from mood disorders including MDD (54). Distributions of TP53 Arg72Pro genotypes in our control group are almost identical to those reported for the European white, comparable in ethnicity and latitude $(24,55,56)$. We found a preferential loss of the 72Pro allele in MDD patients. Inverse association of homozygous TP53 -Pro72 genotype with decreased risk of MDD was shown in women $(\mathrm{OR}=0.18 ; 95 \%$ CI: $0.02-1.42 ; \mathrm{p}=0.04)$ in a recessive model. The Arg72 variant of TP53, but not Pro72, has been described in vitro in primary cultured neurons to have a higher capacity to trigger neuronal apoptosis (57). Furthemore, the Arg72 but not Pro72 was shown to be localized in the mitochondria leading to cytochrome c release from the mitochondria to the cytosol and indicating the mechanism of apoptosis as mitochondrial (intrinsic) apoptotic pathway 
(57). Recent literature data at least in cultured cell systems show long term effects of lithium on the apoptosis induced by various stimuli, Bcl-2 up regulation and p53 and Bax down regulation and suggest possible association between the action of lithium and mood stabilization (58). It should be interesting to investigate possible association between TP53 Arg72Pro polymorphism and degree of prophylactic response to lithium in patients with MDD.

Major limitations of this study are that it has low power to detect significant associations and that the confounding factors such as smoking, alcohol consumption, dietary nutritional habits, and other environmental impacts have not been analyzed in this study, as detailed information could not be obtained from clinical records.

Moreover, a comprehensive epigenetic analysis of candidate SNPs is desirable as could be shed new light on the gender differences observed in our association study.

In conclusion, our study provides evidence that particularly TP53 Arg72Pro polymorphism may contribute to the depression aetiology in the Slovak population. The potential future role of $E G F \mathrm{~A} 61 \mathrm{G}$ and $I G F B P-3 \mathrm{G} 32 \mathrm{C}$ may lie in their ability to identify patients at risk for developing MDD. However, novel correlations require verification in other large patient populations with MDD, particularly in other races/ethnics, since our population was overwhelmingly Caucasian.

\section{Acknowledgements}

This work was partially supported by projects „Biomedical Center Martin" ITMS code: 26220220187, "Competence centre for research and development in diagnosis and therapy" code: 26220220153, "Centre of excellency for research in personalized therapy (CEVYPET)", code: 26-220120053 and 26220220114 "Identification of novel markers in the diagnostic panel of neurological diseases" co-financed from EU sources and the European Regional Development Fund and 2012/30-UKMA-7: Biological and molecular markers of multiple sclerosis from the Ministry of Health of the Slovak Republic and APVV 15/0107.

\section{Conflict of Interests}

None declared

\section{REFERENCES}

1. Wittchen HU, Jacobi F. Size and burden of mental disorders in Europe-a critical review and appraisal of 27 studies. Eur Neuropsychopharmacol. 2005 Aug;15(4):357-76.

2. Van de Velde S, Bracke P, Levecque K. Gender differences in depression in 23 European countries. Cross-national variation in the gender gap in depression. Soc Sci Med. 2010 Jul;71(2):305-13.

3. Celano CM, Freudenreich O, Fernandez-Robles C, Stern TA, Caro MA, Huffman JC. Depressogenic effects of medications: a review. Dialogues Clin Neurosci. 2011;13(1):109-25.

4. Lohoff FW. Overview of the genetics of Major Depressive Disorders. Curr Psychiatry Rep. 2010 Dec;12(6):539-46.

5. Insel, TR, Scolnick EM. Cure therapeutics and strategic prevention: raising the bar for mental health research. Mol Psychiatry. 2006 Jan;11(1):117.

6. Krishnan V, Nestler EJ. The molecular neurobiology of depression. Nature. 2008 Oct 16;455(7215):894-902.

7. Fournier NM, Duman RS. Role of VEGF in adult hippocampal neurogenesis: implications for the pathophysiology and treatment of depression. Behav Brain Res. 2012 Feb 14;227(2):440-9.

8. Duman RS, Li N. A neurotrophic hypothesis of depression: role of synaptogenesis in the actions of NMDA receptor antagonists. Philos Trans R Soc Lond B Biol Sci. 2012 Sep 5;367(1601):2475-84.
9. Evinova A, Babusikova E, Straka S, Ondrejka I, Lehotsky J. Analysis of genetic polymorphisms of brain-derived neurotrophic factor and methylenetetrahydrofolate reductase in depressed patients in a Slovak (Caucasian) population. Gen Physiol Biophys. 2012 Dec;31(4):415-22.

10. Qian J, Zhou H, Chen J, Ding Q, Cao Q, Qin C, et al. Genetic polymorphisms in IGF-I and IGFBP-3 are associated with prostate cancer in the Chinese population. PLoS One. 2014 Feb 21;9(2):e85609. doi: 10.1371/ journal.pone.0085609.

11. Kopczak A, Stalla GK, Uhr M, Lucae S, Hennings J, Ising M, et al. IGF-I in major depression and antidepressant treatment response. Eur Neuropsychopharmacol. 2015 Jun;25(6):864-72.

12. Tu KY, Wu MK, Chen YW, Lin PY, Wang HY, Wu CK, et al. Significantly higher peripheral insulin-like growth factor-1 levels in patients with major depressive disorder or bipolar disorder than in healthy controls: a metaanalysis and review under guideline of PRISMA. Medicine (Baltimore). 2016 Jan;95(4):e2411. doi: 10.1097/MD.0000000000002411.

13. Bot M, Milaneschi Y, Penninx BW, Drent ML. Plasma insulin-like growth factor I levels are higher in depressive and anxiety disorders, but lower in antidepressant medication users. Psychoneuroendocrinology. 2016 Jun;68:148-55.

14. Kim YK, Na KS, Hwang JA, Yoon HK, Lee HJ, Hahn SW, et al. High insulin-like growth factor-1 in patients with bipolar I disorder: a trait marker? J Affect Disord. 2013 Nov;151(2):738-43.

15. Jogie-Brahim S, Feldman D, Oh Y. Unraveling insulin-like growth factor binding protein-3 actions in human disease. Endocr Rev. 2009 Aug;30(5):417-37.

16. Kalluri HS, Dempsey RJ. IGFBP-3 inhibits the proliferation of neural progenitor cells. Neurochem Res. 2011 Mar;36(3):406-11.

17. Basta-Kaim A, Szczesny E, Glombik K, Slusarczyk J, Trojan E, Tomaszewski KA, et al. Prenatal stress leads to changes in IGF-1 binding proteins network in the hippocampus and frontal cortex of adult male rat. Neuroscience. 2014 Aug 22;274:59-68.

18. Vogel T. Insulin/IGF-signalling in embryonic and adult neural proliferation and differentiation in the mammalian central nervous system. In: Wislet-Gendebien S, editor. Trends in cell signaling pathways in neuronal fate decision [Internet]. Rijeka: InTech; 2013. p. 37-73 [cited 2016 Apr 27]. Available from: http://www.intechopen.com/books/trends-in-cellsignaling-pathways-in-neuronal-fate-decision/insulin-igf-signalling-inembryonic-and-adult-neural-prolife ration-and-differentiation-in-themammal.

19. Deal C, Ma J, Wilkin F, Paquette J, Rozen F, Ge B, et al. Novel promoter polymorphism in insulin-like growth factor-binding protein-3: correlation with serum levels and interaction with known regulators. J Clin Endocrinol Metab. 2001 Mar;86(3):1274-80.

20. Jernström H, Deal C, Wilkin F, Chu W, Tao Y, Majeed N, et al. Genetic and nongenetic factors associated with variation of plasma levels of insulin-like growth factor-I and insulin-like growth factor-binding protein-3 in healthy premenopausal women. Cancer Epidemiol Biomarkers Prev. 2001 Apr;10(4):377-84.

21. Zou T, Fleisher AS, Kong D, Yin J, Souza RF, Wang S, et al. Sequence alterations of insulin-like growth factor binding protein 3 in neoplastic and normal gastrointestinal tissues. Cancer Res. 1998 Nov 1;58(21):4802-4.

22. Morimoto LM, Newcomb PA, White E, Bigler J, Potter JD. Insulin-like growth factor polymorphisms and colorectal cancer risk. Cancer Epidemiol Biomarkers Prev. 2005 May;14(5):1204-11.

23. Carpenter G, Cohen S. Epidermal growth factor. Annu Rev Biochem. 1979;48:193-216.

24. Mahmood S, Kmet'ová Sivoňová M, Matáková T, Dobrota D, Dzian A, Wsolova L, et al. Association of EGF and p53 gene polymorphisms and colorectal cancer risk in the Slovak population. Cent Eur J Med. 2014;9(3):405-16.

25. Iwakura Y, Zheng Y, Sibilia M, Abe Y, Piao YS, Yokomaku D, et al. Qualitative and quantitative re-evaluation of epidermal growth factorErbB1 action on developing midbrain dopaminergic neurons in vivo and in vitro: target-derived neurotrophic signaling (Part 1). J Neurochem. $2011 \mathrm{Jul} ; 118(1): 45-56$.

26. Eda T, Mizuno M, Araki K, Iwakura Y, Namba H, Sotoyama H, et al. Neurobehavioral deficits of epidermal growth factor-overexpressing transgenic mice: impact on dopamine metabolism. Neurosci Lett. 2013 Jun 28;547:21-5.

27. Tian W, Zhang J, Zhang K, Yang H, Sun Y, Shen Y, et al. A study of the functional significance of epidermal growth factor in major depressive disorder. Psychiatr Genet. 2012 Aug;22(4):161-7.

28. Futamura T, Toyooka K, Iritani S, Niizato K, Nakamura R, Tsuchiya K, et al. Abnormal expression of epidermal growth factor and its receptor 
in the forebrain and serum of schizophrenic patients. Mol Psychiatry. 2002;7(7):673-82.

29. Hänninen K, Katila H, Anttila S, Rontu R, Maaskola J, Hurme M, et al. Epidermal growth factor a61g polymorphism is associated with the age of onset of schizophrenia in male patients. J Psychiatr Res. 2007 JanFeb;41(1-2):8-14.

30. Lee KY, Ahn YM, Joo EJ, Joo YH, Chang JS, Yoo HY, et al. Partial evidence of an association between epidermal growth factor A61G polymorphism and age at onset in male schizophrenia. Neurosci Res. 2006 Dec;56(4):356-62

31. Shahbazi M, Pravica V, Nasreen N, Fakhoury H, Fryer AA, Strange RC, et al. Association between functional polymorphism in EGF gene and malignant melanoma. Lancet. 2002 Feb 2;359(9304):397-401.

32. Levine AJ. p53, the cellular gatekeeper for growth and division. Cell. $1997 \mathrm{Feb} 7 ; 88(3): 323-31$.

33. Komarova EA, Chernov MV, Franks R, Wang K, Armin G, Zelnick CR, et al. Transgenic mice with p53-responsive lacZ: p53 activity varies dramatically during normal development and determines radiation and drug sensitivity in vivo. EMBO J. 1997 Mar 17;16(6):1391-400.

34. Zhang C, Wu Z, Hong W, Wang Z, Peng D, Chen J, et al. Influence of BCL2 gene in major depression susceptibility and antidepressant treatment outcome. J Affect Disord. 2014 Feb;155:288-94.

35. Olivier M, Eeles R, Hollstein M, Khan MA, Harris CC, Hainaut P. The IARC TP53 database: new online mutation analysis and recommendations to users. Hum Mutat. 2002 Jun;19(6):607-14.

36. Thomas M, Kalita A, Labrecque S, Pim D, Banks L, Matlashewski G. Two polymorphic variants of wild-type p53 differ biochemically and biologically. Mol Cell Biol. 1999 Feb;19(2):1092-100.

37. Sakamuro D, Sabbatini P, White E, Prendergast GC. The polyproline region of p53 is required to activate apoptosis but not growth arrest. Oncogene. 1997 Aug 18;15(8):887-98.

38. Azzam GA, Frank AK, Hollstein M, Murphy ME. Tissue-specific apoptotic effects of the p 53 codon 72 polymorphism in a mouse model. Cell Cycle. 2011;10(9):1352-5.

39. SNP \& Variation Suite ${ }^{\mathrm{TM}}$. Version 8.x [software]. Bozeman, MT: Golden Helix, Inc. Available from http://www.goldenhelix.com

40. Szczęsny E, Slusarczyk J, Głombik K, Budziszewska B, Kubera M, Lason W, et al. Possible contribution of IGF-1 to depressive disorder. Pharmacolog. Pharmacol Rep. 2013;65(6):1622-31.

41. Harrela M, Koistinen H, Kaprio J, Lehtovirta M, Tuomilehto J, Eriksson J, et al. Genetic and environmental components of interindividual variation in circulating levels of IGF-I, IGF-II, IGFBP-1, and IGFBP-3. J Clin Invest. 1996 Dec 1;98(11):2612-5.

42. Licht CM, van Turenhout LC, Deijen JB, Koppes LL, van Mechelen W, Twisk JW, et al. The association between igf-1 polymorphisms, igf- 1 serum levels, and cognitive functions in healthy adults: the Amsterdam Growth and Health Longitudinal Study. Int J Endocrinol. 2014;2014:181327. doi: 10.1155/2014/181327.

43. D'Aloisio AA. Evaluation of insulin-like growth factor polymorphisms with prevalence and size of uterine leiomyomata [dissertation]. Chapel Hill: University of North Carolina; 2007.

44. Duron E, Funalot B, Brunel N, Coste J, Quinquis L, Viollet C, et al. Insulin-like growth factor-I and insulin-like growth factor binding protein-3 in Alzheimer's disease. J Clin Endocrinol Metab. 2012 Dec;97(12):4673-81

45. Green CJ, Holly JM, Bayer A, Fish M, Ebrahim S, Gallacher J, et al. The role of IGF-I, IGF-II, and IGFBP-3 in male cognitive aging and dementia risk: the Caerphilly Prospective Study. J Alzheimers Dis. 2014;41(3):86775 .
46. Johansson P, Åberg D, Johansson JO, Mattsson N, Hansson O, Ahrén $\mathrm{B}$, et al. Serum but not cerebrospinal fluid levels of insulin-like growth factor-I (IGF-I) and IGF-binding protein-3 (IGFBP-3) are increased in Alzheimer's disease. Psychoneuroendocrinology. 2013 Sep;38(9):172937.

47. Emeny RT, Bidlingmaier M, Lacruz ME, Linkohr B, Peters A, Reincke M, et al. Mind over hormones: sex differences in associations of well-being with IGF-I, IGFBP-3 and physical activity in the KORA-Age study. Exp Gerontol. 2014 Nov;59:58-64.

48. Cheng I, DeLellis Henderson K, Haiman CA, Kolonel LN, Henderson $\mathrm{BE}$, Freedman ML, et al. Genetic determinants of circulating insulin-like growth factor (IGF)-I, IGF binding protein (BP)-1, and IGFBP-3 levels in a multiethnic population. J Clin Endocrinol Metab. 2007 Sep;92(9):36606.

49. D'Aloisio AA, Schroeder JC, North KE, Poole C, West SL, Travlos GS, et al. IGF-I and IGFBP-3 polymorphisms in relation to circulating levels among African American and Caucasian women. Cancer Epidemiol Biomarkers Prev. 2009 Mar;18(3):954-66.

50. Mill J, Petronis A. Molecular studies of major depressive disorder: the epigenetic perspective. Mol Psychiatry. 2007 Sep;12(9):799-814.

51. Lim YJ, Kim JW, Song JY, Hong MS, Jin SY, Yoon SH, et al. Epiderma growth factor gene polymorphism is different between schizophrenia and lung cancer patients in Korean population. Neurosci Lett. $2005 \mathrm{Feb}$ 21;374(3):157-60.

52. Watanabe Y, Fukui N, Muratake T, Kaneko N, Someya T. No association of EGF polymorphism with schizophrenia in a Japanese population. Neuroreport. 2005 Mar 15;16(4):403-5.

53. Anttila S, Illi A, Kampman O, Mattila KM, Lehtimäki T, Leinonen E. Association of EGF polymorphism with schizophrenia in Finnish men. Neuroreport. 2004 May 19;15(7):1215-8.

54. Eilat E, Mendlovic S, Doron A, Zakuth V, Spirer Z. Increased apoptosis in patients with major depression: a preliminary study. J Immunol. 1999 Jul 1;163(1):533-4.

55. Tenti P, Vesentini N, Rondo Spaudo M, Zappatore R, Migliora P, Carnevali $\mathrm{L}$, et al. p53 codon 72 polymorphism does not affect the risk of cervical cancer in patients from northern Italy. Cancer Epidemiol Biomarkers Prev. 2000 Apr;9(4):435-8

56. Scheckenbach K, Lieven O, Götte K, Bockmühl U, Zotz R, Bier H, et al. p53 codon 72 polymorphic variants, loss of allele-specific transcription, and human papilloma virus 16 and/or 18 E6 messenger RNA expression in squamous cell carcinomas of the head and neck. Cancer Epidemiol Biomarkers Prev. 2004 Nov;13(11 Pt 1):1805-9.

57. Gomez-Sanchez JC, Delgado-Esteban M, Rodriguez-Hernandez I, Sobrino T, Perez de la Ossa N, Reverte S, et al. The human Tp53 Arg72Pro polymorphism explains different functional prognosis in stroke. J Exp Med. 2011 Mar 14;208(3):429-37.

58. Karlović D, Buljan D. Apoptosis - the potential pathophysiological mechanism in mood disorders modifiable by lithium salts. Biochemia Medica. 2008;18(3):291-310. (In English, Croatian.)

Received February 2, 2015 Accepted in revised form April 27, 2016 